mie dochodzi do błędnego określenia takiego niespójnego tekstu, który tylko został przeczytany nieuważnie. Wypada więc mieć nadzieję, że Formgeschichte w patrystyce nie stanie się metodą do przysłowiowego „cięcia tekstów na kawałki" dla zabawy, jak to czyniono przez wiele lat w studiach biblijnych. Wyodrębnione $w$ ten sposób formy i próba ich ponownego układania inaczej, niż to uczynił ostateczny redaktor, będą bowiem na tyle hipotetyczne, że niemożliwe do zweryfikowania.

ks. Leszek Misiarczyk - Płock

\title{
Danil HOMBERGEN OCSO, The Second Origenist Controversy. A New Perspective on Cyril of Scythopolis' Monastic Biographies as Historical Sour- ces for Sixth-Century Origenism, Studia Anselmiana 132, Roma 2001, ss. 448.
}

Ogromna bibliografia orygenesowska ostatnich 80 lat obejmuje głównie pozycje dotyczące jego osoby i doktryny filozoficzno-teologicznej ${ }^{1}$. Stosunkowo mniej opracowań poświęcono natomiast pośmiertnym burzliwym dziejom jego myśli w okresie patrystycznym, zwłaszcza tzw. sporom orygenesowskim². W języku polskim bibliografia dotycząca owych sporów jest bardzo skromna i nie wykracza poza syntetyczne artykuły dające ogólną, podstawową wizję zjawiska, określanego tym mianem ${ }^{3}$.

Przejawem wzrastającego $\mathrm{w}$ ostatnim czasie zainteresowania kwestią pierwszej fali kontrowersji, związanych z osobą i myślą „Adamantiusa" w IV wieku jest sympozjum orygeniańskie, jakie odbyło się w Niemczech w 1997 roku ${ }^{4}$. Do tego samego nurtu pogłębionych badań nad dyskusją orygeniańską po śmierci wielkiego Aleksandryjczyka włącza się recenzowana rozprawa dok-

${ }^{1}$ Por. H. Crouzel, Bibliographie critique d'Origène, Instrumenta Patristica 8, Steenbrugge La Haye 1971; tenże, Bibliographie critique d'Origène. Supplément 1, Instrumenta Patristica 8 A, Steenbrugge - La Haye 1982; tenże, Bibliographie critique d'Origène. Supplément 2, Instrumenta Patristica 8 B, Steenbrugge - La Haye 1996.

2 Podstawowe prace omawiające to zagadnienie: A. Guillaumont, Les „Képhalaia gnostica” d'Évagre le Pontique et l'histoire de l'origenisme chez les Grecs et chez les Syriens, Patristica Sorbonensia 5, Paris 1962; L. Perrone, La Chiesa di Palestina e le controversie cristologiche. Dal Concilio di Efeso (431) al secondo Concilio di Constantinopoli (553), Testi e ricerche di Scienze religiose 18, Brescia 1980; L'Origenismo. Apologie e polemiche intorno a Origene (XIV Incontro di studiosi dell'Antichità cristiana, 9-11 Maggio 1985), „Augustinianum” 26 (1986); E. Clark, The Origenist Controversy. The cultural construction of an Early Christian debate, Princeton 1992.

${ }^{3}$ Por. A. Zajkowski, Orygenesowskie spory, SWP 307-309; S. Longosz, Orygenizm i spory wokót Orygenesa (w 1800-lecie urodzin), VoxP 5 (1985) z. 8-9, 395-412.

${ }^{4}$ Kompletne materiały z tego VII, odbywającego się co 4 lata Kolokwium Orygenesowskiego, zostały w całości opublikowane: Origeniana Septima. Origenes in den Auseinandersetzungen des 4. Jahrhunderts (VII Ih International Colloquium on Origen, Hofgeismar - Marburg, 25-29 August 1997), ed. W. Bienert - U. Kühneweg, Leuven 1999. 
torska D. Hombergena. Przedmiotem badań Autora stały się biografie mnichów pióra Cyryla ze Scytopolis (ok. 525-559) - głównie Vita Sabae - pod kątem ich przydatności jako źródła historycznego do badań nad orygenizmem VI wieku, czyli w drugiej zasadniczej fazie sporów orygenesowskich, związanej ze środowiskiem mnichów palestyńskich.

O ile w przypadku pierwszej fazy sporów orygenenesowskich w IV wieku dysponujemy dokumentacją pochodzącą od obu stron konfliktu, o tyle w odniesieniu do okresu drugiej wielkiej kontrowersji w VI wieku, jesteśmy zdani niemal wyłącznie na źródła wywodzące się z obozu wrogiego orygenistom. Cyryl - główny dziejopis tych wydarzeń - byl zdecydowanym przeciwnikiem orygenizmu, przekonanym, że podczas V soboru ekumenicznego w Konstantynopolu w $553 \mathrm{r}$. rzeczywiście potępiono naukę Orygenesa ${ }^{5}$. To stanowisko Cyryla powinno wzbudzać pewną wątpliwość co do jego bezstronności w relacjonowaniu faktów. Tymczasem wśród naukowców, oprócz nielicznych wyjątków (przede wszystkim M. Simonetti, zarzucający Cyrylowi tendencyjność i powierzchowność), cieszy się on reputacją historyka dbającego o precyzję chronologiczną, prawdomównego i godnego zaufania (4. punkt obszernego wprowadzenia do książki jest poświęcony dokładnemu przeglądowi stanowisk badaczy, począwszy od XVII w.). Budzi to słuszne podejrzenie Hombergena, który podkreśla, ze Cyryl był od dzieciństwa uczniem św. Saby i jako młody mnich zaangażował się w ostatnią i decydującą fazę kontrowersji orygeniańskiej po stronie obozu przeciwników orygenizmu. Fakt ten powinien wywoływać, zdaniem Autora, uzasadnione obawy co do prawdomówności Cyryla w ocenie, zarówno doktrynalnej strony orygenizmu, jak i środowiska mnichów, reprezentujących to stanowisko. Nota bene, trzeba pamiętać, że termin „orygenizm" w odniesieniu do zjawisk VI w. jest bardzo niejednoznaczny, obejmuje bowiem stanowiska różnych mnichów i ma niewiele wspólnego z rzeczywistą nauką samego Orygenesa. Autor recenzowanej książki stawia tezę o wynikającej z powyższych przesłanek nieobiektywności i tendencyjności przekazów Cyryla, i ogranicza tym samym jego wartość jako źródła historycznego. Cała rozprawa Hombergena służy weryfikacji tej tezy na podstawie dokładnej analizy materiału źródłowego.

W rozdziale I (The Victory of Orthodoxy. Edifying Stories within the Framework of a Monastic Biography, s. 57-130), po szczegółowej charakterystyce corpus Cyrillianum, Autor analizuje przedstawioną w ośmiu ostatnich rozdziałach Vita Sabae historię orygenizmu w latach 532-554, w świetle reprezentowanego przez to dzieło literackiego gatunku biografii monastycznej, wywodzącego się od Vita Antonii Atanazego. Specyfiką tego gatunku literackiego była pewna służebność narracji historycznej wobec nadrzędnych przesłanek hagio-

${ }^{5} \mathrm{Na}$ temat tej kwestii zob. najnowsze stanowisko $\mathrm{H}$. Crouzela, Les condamnations subies par Origène et sa doctrine, w: Origeniana Septima, s. 311-315. 
graficznych. Hombergen dowodzi, że zgodnie z ową specyfiką gatunkową, a także z własnymi przekonaniami, Cyryl ujawnił w Vita Sabae hagiograficzną tendencję wyolbrzymiania zalet świętego bohatera walczącego w obronie ortodoksji. Omówione w końcowych rozdzialach dzieje orygenizmu w dwudziestoleciu po śmierci Saby nie są więc wyizolowanym $z$ dzieła „,appendixem", ale stanowią zaplanowaną przez autora kulminację całego życia bohatera żywotu: zwycięstwo nad orygenizmem zostało przedstawione jako swoiste miraculum post mortem św. Saby, będące potwierdzeniem jego ścisłej lączności z Bogiem (parrhsa). Autor opracowania, powołując się na ustalenia teoretyków wczesnochrześcijańskiej hagiografii (H. Delahaye, M. Van Uytfanghe), zauważa, że wydarzenia przedstawione w Vita Sabae mogły ulec stylizacji, wywodzącej się z trzech źródeł: od samego Saby, od jego zwolenników, wreszcie od samego Cyryla. Tego typu zabiegi w dyskursie hagiograficznym, wciąż zgodne ze specyfiką gatunku, służyły $z$ jednej strony apologii i idealizacji bohatera, $\mathrm{z}$ drugiejpouczeniu, zbudowaniu czytelnika i zachęceniu go do naśladowania świętego oraz oddawania mu czci. Cyryl miał również na celu stworzenie hagiografii palestyńskiej, która mogłaby konkurować $z$ egipską i syryjską; zależało mu równocześnie na ukazaniu hegemonii ortodoksyjnego monastycyzmu w patriarchacie jerozolimskim.

W celu zbadania obiektywności przekazu Cyryla o zakończeniu sporów orygenesowskich, Hombergen porównuje Vita Sabae Cyryla z Vita Theodosii Teodora z Petry, które to dzieło uchodzi w porównaniu z „historycznym” stylem Cyryla za pełen retoryki panegiryk. Ta różnica stylu nie oznacza jednak, zdaniem Autora rozprawy, że można zawsze ufać przekazowi mnicha ze Scytopolis. Dowodem idealizacji Cyrylowej biografii jest dla Hombergena ukazanie w niej abby Teodozjusza (ok. 430-529), jako wielkiego przyjaciela Saby i przemilczenie kryzysu między anachoretami i cenobitami, podczas gdy Teodor z Petra w Vita Theodosii kompletnie pomija postać Saby, również nieobiektywnie monopolizując inicjatywę $\mathrm{w}$ walce $\mathrm{z}$ orygenizmem i przypisując ją niepodzielnie własnemu bohaterowi. Tak więc obaj autorzy za nadrzędny cel swoich przekazów uważają ukazanie w jak najbardziej pozytywnym świetle prezentowanego bohatera danego żywotu. Hombergen słusznie wnioskuje na podstawie przeprowadzonych analiz, że podchodząc do Vita Sabae Cyryla jako źródła historycznego, trzeba być świadomym obecnych w nim hagiograficznych transformacji prawdy historycznej.

W II rozdziale omawianej monografii („Origenism” and „Anti-Origenism. In Search of the Underlying Conflict, ss. 131-254) autor dowodzi, że opozycyjne ugrupowania sporu orygenesowskiego w czasach Cyryla dzieliło więcej kwestii, niż tylko stanowisko wobec tzw. orygenizmu. Konflikt był zjawiskiem złożonym i obejmował kilka wymiarów: chrystologiczny, duchowy, intelektualny i polityczny. Do powyższych wniosków Hombergen dochodzi analizując Cyrylowy opis postaci mnicha Leoncjusza z Bizancjum, krytykowanego przez $\mathrm{Cy}$ - 
ryla za orygenizm i uznawanego przez niego za jednego $\mathrm{z}$ czołowych przedstawicieli partii orygenistów. Obraz ten jest niezgodny z zachowanymi dzielami przypisywanymi Leoncjuszowi, które nie zawierają wyraźnych śladów wpływu doktryny orygenesowskiej. W świetle porównawczych badań Hombergena Leoncjusz jawi się w swych dziełach jako zwolennik doktryny chalcedońskiej i obrońca formuły chrystologicznej o dwóch naturach w jednej osobie, podczas gdy Cyryl przedstawia „swojego" Leoncjusza jako ukrytego orygenistę, udającego jedynie obrońcę Soboru Chalcedońskiego.

Autor opracowania usiłuje najpierw dociec, czy istotnie w obu przypadkach chodzi o tego samego Leoncjusza, jak to usiłowal dowieść, mimo wszelkich wątpliwości F. Loofs, w swojej monografii poświęconej osobie tajemniczego mnicha z Bizancjum ${ }^{6}$. Analizy Hombergena potwierdzają hipotezę Loofsa, przyjmowaną przez wielu współczesnych uczonych, że autorem trzech dzieł $\mathrm{z}$ tzw. „corpus leontinianum" (Contra Nestorianos et Eutychianos, Triginta capita adversus Severum, Epilysis) jest Leoncjusz Eremita, identyczny z opisywanym przez Cyryla ze Skytopolis Leoncjuszem z Bizancjum. Był on silnie związany z grupą osób, czerpiących inspiracje z pism tzw. „teozofów”, do których należał Ewagriusz. Srodowisko to zmusiło Leoncjusza do ataku na Teodora z Mopsuestii, który związany był z kręgami antyoregenesowskimi. Spór orygenesowski wydaje się więc mieć związek z inną wielką kontrowersją teologiczną owego czasu - ze sporem o „Trzy Rozdziały”, o którym Cyryl milczy niemal zupełnie. Według Hombergena Cyryl zarzuca Leoncjuszowi kryptoorygenizm, podczas gdy z pism tego ostatniego wynika, że byl on nie tyle zwolennikiem doktrynalnych błędów przypisywanych orygenistom (wobec teorii o preegzystencji dusz i apokatastazy zajmował on pozycję, łagodnie mówiąc, obojętną), co przeciwnikiem kryptonestorianizmu zarzucanego przez niego antyorygenistom. Ci zaś, łącznie z Cyrylem, chcąc zachować ortodoksję, musieli zdystansować się od osoby Teodora z Mopsuestii, stąd anachroniczne stwierdzenia Cyryla, że Saba i jego następca Gelazy już w 531 i 546 r., czyli na długo przed soborem, wyrzekli się poglądów Teodora. Tak więc, zdaniem Autora recenzowanej monografii, karykaturalny obraz Leoncjusza nakreślony przez Cyryla nie jest prawdziwy, ale uwarunkowany konfliktem przekraczającym ramy doktrynalnego sporu o uznawanie tez orygenesowskich i związanym raczej $\mathrm{z}$ opozycją między Aleksandryjczykami i Antiocheńczykami w okresie poprzedzającym bezpośrednio sobór w 553 roku.

Jak pisze Hombergen (s. 177), ,a methodological doubt about Cyril of Scythopolis' historical trustworthiness could open a new line for further research". To metodologiczne wątpienie wobec prawdziwości historycznego przekazu Cyryla prowadzi Autora książki do szczegółowego zbadania duchowych $\mathrm{i}$ intelektualnych aspektów sporu orygenesowskiego w VI wieku. Z analiz

\footnotetext{
${ }^{6}$ Por. F. Loofs, Leontius von Byzanz, TU 3/1, Leipzig 1887.
} 
materiału źródłowego przeprowadzonych przez Hombergena wynika, że druga kontrowersja orygenesowska nie była zwykłym konfliktem między intelektualizmem mnichów orygenistów a antyintelektualizmem ich przeciwników. Cyryla i innych antyorygenistów należy bowiem również uznać za intelektualistów. Ich stanowisko było jednak związane $z$ wykorzystaniem w walce przeciw orygenistom szeroko rozpowszechnionego w monastycyzmie VI wieku ideału prostoty ( $\alpha \dot{\phi} \dot{\lambda} \lambda \varepsilon \imath \alpha)$, wiązanego z ortodoksyjnością w wierze. Nie chodziło w nim o propagowanie braku wykształcenia, ale o zwrócenie uwagi na szukanie woli Boga, jako przeciwstawienie ludzkich wysiłków podejmowanych przez kulturę świecką. Antyorygeniści, a wśród nich Cyryl, stawiali przede wszystkim opór integracji miedzy filozoficznym dziedzictwem hellenizmu a duchową tradycją monastyczną. Zarzucali swoim adwersarzom marnowanie czasu na próżne spekulacje intelektualne i zaniedbywanie praktyk ascetycznych. W świetle ustaleń Hombergena spory orygenesowskie VI wieku są więc w dużym stopniu walką między dwiema wizjami życia duchowego. Cała złożoność ówczesnej sytuacji wpłynęła, zdaniem autora monografii, na hagiograficzną stylizację rzeczywistości historycznej przez Cyryla.

Rozdział III omawianej monografii (The Combat. Inaccurate Charges, Distortions and Clashing Ideals, ss. 255-368) stanowi kontynuację prezentacji materiału dowodowego, potwierdzającego tezę o ułomności i tendencyjności obrazu orygenizmu VI wieku, przedstawionego w dziełach Cyryla ze Scytopolis. Autor dokonuje w nim szczegółowej analizy dwóch istotnych tekstów Cyryla: tyrady abby Cyriakusa przeciw orygenistom, łącznie z Leoncjuszem z Bizancjum (Vita Cyriaci 11-15), oraz opisu wydarzeń związanych z V Soborem ekumenicznym w 553 r. (Vita Sabae 90). Zarzuty z pierwszego tekstu Hombergen porównuje $\mathrm{z}$ innymi przekazami źródłowymi: nie tylko $\mathrm{z}$ oficjalnymi dokumentami antyorygenesowskimi, ale także z pismami samego Orygenesa oraz Ewagriusza i Leoncjusza. Dochodzi do wniosku, że dyskurs zapisany przez Cyryla nie zostal wygłoszony w takiej formie przez Cyriakusa ok. 544 r., ale został skomponowany przez samego Cyryla o wiele później, nawet $\mathrm{z}$ wykorzystaniem oficjalnego tekstu anatematyzmów Soboru w 553 roku. Hombergen dokonuje weryfikacji pochodzenia błędnych twierdzeń przypisywanych przez Cyryla orygenistom (Chrystus nie należy do Trójcy; ciała zmartwychwstałe ulegną całkowitej destrukcji; Trójca nie jest stwórcą świata, a przy odnowieniu wszystkiego każdy byt racjonalny, nawet szatan, będzie zdolny do stwarzania eonów; wszystkie ciała po zmartwychwstaniu będą eteryczne i kuliste; wszyscy ludzie będą równi Chrystusowi); stwierdza, że są one zgodne z anatematyzmami Soboru i spekulacjami Ewagriusza, nie mają natomiast prawie nic wspólnego nie tylko $\mathrm{z}$ poglądami samego Orygenesa, ale również z nauką zawartą w pismach Leoncjusza. Cyryl zapożyczył więc $z$ anatematyzmów Soboru kilka stereotypowych zarzutów i uzył ich w sposób nieuprawniony w odniesieniu do całego ruchu orygenesowskie- 
go w VI wieku, tworząc w ten sposób tendencyjnie ciemny jego obraz pod względem doktrynalnym.

Drugi tekst poddany krytycznej analizie przez Hombergena to ostatni rozdzial Vita Sabae, w którym Cyryl przedstawia własną wersję potępienia orygenizmu, uznając tę kwestię za główne wydarzenie związane z V Soborem ekumenicznym w 553 roku. Eksponuje ją tak bardzo, że odnosi się wrażenie, iż Sobór został zwołany w celu rozwiązania problemu orygenizmu, a nie z powodu sporu o „Trzy Rozdziały”, który został wspomniany tylko na marginesie. W przekazie Cyryla główna rola w wydarzeniach prowadzących do przezwyciężenia orygenizmu została przypisana abbie Cononowi, następcy św. Saby na stanowisku przełożonego wspólnoty anachoreckiej. Zdaniem Hombergena, nie jest to w pełni zgodne $z$ prawdą historyczną, ale stanowi charakterystyczne dla gatunku hagiograficznego wywyższenie bohatera żywotu przez pokazanie w jak najkorzystniejszym świetle jego następcy. Hagiograficzna idealizacja znajduje swój wyraz również w kończącym żywot nastroju radości z powodu zwycięstwa antyorygenistów nad ich przeciwnikami, który w 557 r., zamykającym ramy czasowe Vita Sabae, był z pewnością przedwczesny.

Rzeczowe, inteligentnie przeprowadzone w całej pracy analizy porównawcze, dokumentują bezspornie tezę o względnej przydatności żywotów Cyryla ze Scytopolis dla badań mających na celu wierną rekonstrukcję wydarzeń związanych $\mathrm{z}$ drugą kontrowersją orygenesowską. Jego obraz orygenizmu w VI wieku jest tendencyjny i przesadzony, podporządkowany nadrzędnemu celowi, jakim jest wyidealizowane przedstawienie św. Saby. Monografia Hombergena stanowi znakomity przykład podejścia do patrystycznych tekstów źródłowych $\mathrm{z}$ uwzględnieniem specyfiki gatunku literackiego, jaki one reprezentują. Tylko taki sposób podejścia gwarantuje obiektywizm w badaniach, sięga istoty tekstu i posuwa naprzód wiedzę zarówno o literaturze patrystycznej, jak i o dziejach Kościoła pierwszych wieków. Wśród polskich badaczy chrześcijańskiego antyku podobną metodę w odniesieniu do łacińskojęzycznych wczesnochrześcijańskich żywotów świętych zastosowal P. Nehring ${ }^{7}$. Praca Hombergena jest w pewnym sensie pokazaniem drugiego, wschodniego oblicza patrystycznej literatury hagiograficznej, zbieżnego $\mathrm{z}$ zachodnim pod względem konkretnych, ściśle przestrzeganych cech gatunkowych, wobec których fakty historyczne musiały pełnić rolę służebną.

Omawiana monografia stanowi ważny przyczynek do badań nad orygenizmem VI wieku. Pokazuje, jak bardzo złożone było to zjawisko, jak daleko odbiegło ono od rzeczywistej nauki Orygenesa i jak nieobiektywnie było oceniane przez adwersarzy (przykład opinii Cyryla o Leoncjuszu z Bizancjum). W świetle takich źródeł, jak żywoty Cyryla, orygeniści VI wieku jawią się jako

\footnotetext{
${ }^{7}$ Por. Topika wczesnych tacinskich żywotów świętych (od „Vita Antonii" do „Vita Augustini"), Toruń 1999.
} 
„homogeniczna grupa heretyków, którzy radykalizując Ewagriańską systematyzację Orygenesowskiej myśli pod wpływem ekstremalnego panteizmu Stefana Bar Sudaili, popchnęli dziedzictwo Orygenesa poza granice ortodoksji i stali się w ten sposób odpowiedzialni za jego potępienie" (s. 369). W gruncie rzeczy jednak, jak stwierdza Hombergen, jest to opinia jednostronna, nie ma bowiem obiektywnych świadectw, pozwalających stwierdzić, kim byli naprawdę palestyńscy orygeniści w VI wieku. Autor pracy wskazuje to zagadnienie jako ważny problem badawczy na przyszłość. Sam próbuje w zakończeniu ostatniego rozdziału, wskazać pewną pozadoktrynalną cechę owego orygenizmu, związaną z rozwojem duchowości monastycznej między IV a VI wiekiem, szczególnie drażniącą antyorygenistów, do których należał Cyryl. Otóż orygeniści reprezentowali pragnienie kultywowania życia kontemplacyjnego, wspieranego judeochrześcijańską tradycją egzegetyczną i dziedzictwem filozofii helleńskiej. W pierwotnym monastycyzmie egipskim IV wieku taka skłonność ku mistycyzmowi była kultywowana na szeroką skalę. Jednakże w VI wieku, w politycznych i kościelnych strukturach wczesnobizantyńskiej teokracji, z jej wrogością wobec spadku po hellenizmie i $z$ przypisywaniem szczególnej roli ruchowi monastycznemu, kwestia indywidualnego postępu duchowego zostala w dużym stopniu podporządkowana celowi zbiorowemu, jakim stała się dobrze zorganizowana zakonna instytucja. Cyryl ze Skytopolis był wlaśnie, jak to pokazuje omawiane studium, głównym przedstawicielem owego zinstytucjonalizowanego monastycyzmu. Orygenizm VI wieku, zdaniem Hombergena, należy rozumieć przede wszystkim jako naturalną reakcję na tę zmianę kierunku w koncepcji życia zakonnego (s. 370). W tej słusznej, jak się wydaje, hipotezie, Hombergen nie chce za wszelką cenę bronić orygenistów. Jest świadomy popełnionych przez nich błędów doktrynalnych; nie uważa ich też za „świętych", twierdząc, że niektóre wzmianki Cyryla o ludzkich emocjach i gwaltowności okazywanej przez orygenistów, wcale nie musiały być przesadzone.

Autor wykorzystal w monografii ogromną literaturę przedmiotu (blisko 30 stron bibliografii!), do której odwołuje się w sposób imponujący znajomością stanowisk w dyskusji między badaczami. Potwierdza bądź weryfikuje ich tezy, dyskutując przy pomocy silnych źródlowych argumentów jak równy $\mathrm{z}$ równym. W bardzo starannie opracowanych przypisach pojawia się szereg cennych informacji historycznych, liczne cytaty greckie oraz częste odwołania do dotychczasowego stanu badań. Książka, przy zachowaniu naukowej precyzji, napisana jest znakomicie pod względem stylistycznym. Wywody Hombergena są logiczne i przejrzyste, czytelnik nigdy nie gubi wątku i przez moment nie ma wątpliwości, o co chodzi autorowi i dokąd prowadzi jego tok myślowy. Ogólnie rzecz biorąc jest to ważne studium, poszerzające wiedzę zarówno o orygenizmie VI wieku, jak i o źródłach służących do jego poznania. Może ono również stanowić wzór solidnie pod względem metodologicznym przygotowanej rozprawy z pogranicza patrologii i historii Kościoła starożytnego. 
Na zakończenie należy zauważyć, że omawiana książka zawiera pewien akcent polski. Otóż w ostatecznej redakcji pomagał autorowi dyrektor młodego, ale już zasłużonego dla polskiej patrologii bydgoskiego wydawnictwa „Homini” - Krzysztof Bielawski. Wypada tylko życzyć, by konsekwencją tego udziału w publikacji rozprawy D. Hombergena, było jej rychłe nowe wydanie, tym razem w języku polskim.

ks. Mariusz Szram - Lublin, KUL

\section{Ks. Mariusz SZRAM, Duchowy sens liczb w alegorycznej egzegezie aleksand- ryjskiej (II-V w.), Lublin 2001, Redakcja Wydawnictw KUL, ss. 470.}

Zainteresowanie spuścizną Ojców Kościoła i pisarzy kościelnych pierwszych wieków już od ponad trzydziestu lat w naszym kraju znacznie się ożywiło. Przyczynilo się do tego kilku wybitnych uczonych, których uczniowie i kontynuatorzy zdążyli już sami pozyskać własnych uczniów i słuchaczy. Jednym $z$ takich uczniów, reprezentujących kolejne już pokolenie badaczy, jest ks. Mariusz Szram, którego praca pomyślana jako rozprawa habilitacyjna z powodzeniem wpisuje się na listę polskich osiągnięć w tej dziedzinie. Trzeba wszakże podkreślić, że problem alegorezy w odniesieniu do liczb we wczesnej tradycji patrystycznej nie znalazł do tej pory w polskiej bibliografii poważniejszego opracowania i tutaj praca ks. Szrama jawi się jako uzupełnienie dotkliwej luki w tym zakresie. Zdaje sobie $\mathrm{z}$ tego sprawę i Autor rozprawy, bo w obszernym wstępie, obejmującym niemal cały arkusz wydawniczy (ss. 7-28), a informującym dokładnie o stanie badań tej problematyki, sam pisze o zamiarze wypełnienia tej luki (s. 19).

W I rozdziale (ss. 29-95) zajął się Autor przedstawieniem nurtów symboliki liczb inspirujących wczesnochrześcijańską egzegezę aleksandryjską. Chcąc dać swemu studium podstawę historyczną, sięgnął najpierw do prac omawiających numerologię platońską i pitagorejską, by następnie przejść do egzegezy numerologicznej u Filona Aleksandryjskiego i kolejno - u pisarzy wczesnochrześcijańskich. Na końcu omawianego rozdziału znajdujemy omówienie symboliki liczb nawet w pismach gnostyckich. Ten szeroki przegląd przed- i wczesnochrześcijańskich oraz gnostyckich koncepcji, dotyczących interpretacji znaczenia liczb, posłużył Autorowi rozprawy za bazę dla kolejnego, II rozdziału (ss. 97-121), w którym przechodzi on już do omówienia założeń aleksandryjskiej egzegezy numerologicznej. Wlaśnie ta część pracy jest swoistym jej jądrem, bowiem przedstawione tutaj zostały znaczenia przypisywane liczbom biblijnym przez poszczególnych autorów aleksandryjskich. Ks. Szram zdaje sobie sprawę, że zakres symboliki liczb był u Aleksandryjczyków bardzo obszerny i obejmowal niekiedy nawet wykluczające się znaczenia. Myślę, że jest 